New Zealand journal of industrial relations, 1983, 8, 211-221

\title{
COMMENTARY
}

\section{The trade union response to structural change}

\begin{abstract}
Alf Kirk*
In looking at the trade union response to the structural changes posed by the dramatic economic events of the 1970s, it is first necessary to look at the background which determined the institutional nature of unions to that change beating upon our shores. Therefore I wish to divide this paper into 4 parts: the social and economic background of the 1950s and 1960s; longer term social changes influencing trade unions; the impact of change and the trade union response; implications.
\end{abstract}

\section{The social and economic background of the 1950 s and $1960 \mathrm{~s}$}

For trade unions the postwar period to the late 1960 s was characterised by 3 major elements. First, a constantly rising level of real income, secondly virtually full employment for a large part of that period, and thirdly, the high emphasis on conciliation and arbitration procedures in determing wage settlements.

The trade union movement as we know it today emerged from the background. It was an environment which encouraged the idea that unions were almost intermediaries between workers and employers; operating on very much the same lines as any bureaucracy in our society. This environment and understanding had some important implications for union organisation and operating methods. There was a limited membership involvement. The process of negotiating was seen as a matter for union professionals with limited involvement by rank and file union members. A concentration upon wages and conditions was regarded as the unions' main job. Concern about wider economic and social affairs were not seen as an important element in union activity. There was also a high level of legalism. The conciliation and arbitration sytem itself encouraged the development of a legalistic approach to wage fixing issues. This reinforced a tendency for economic issues to be increasingly left out of wage negotiations. It is interesting to note that of academics in New Zealand trade unions over the 1950s, 1960s and 1970s, most were lawyers rather than people with economics or social science backgrounds. To a certain degree, the FOL in particular, and the trade union movement generally, acted as a proxy for the Government in keeping wage settlements and conditions within certain constraints. The system moreover tended to encourage unions to concentrate on short term maximisation of monetary rewards and benefits. The development of comprehensive policies within the trade union movement were not well advanced for a number of reasons, one particular reason being the

* Text of a lecture presented as part of the Friends of the Turnbull Library's 1983 Winter Lecture series, "Ways to Change". The editors are grateful to the Friends of the Turnbull Library for permission to publish the lecture. Readers interested in purchasing copies of the full set of lectures should see the advertisement on the page facing.

Alf Kirk was formerly Research Officer, New Zealand Federation of Labour. The views expressed in this lecture are the views of the author and do not necessarily represent the view of the Federation. Given that the author's trade is that of economist it is probable that his opinion in this lecture is only one of a range. 
almost universal desire to leave those matters over to labour's political wing. The results of this are clearly seen today. When one looks at the policy booklet of the FOL it is found that 7 of the 41 pages of that policy booklet are concerned about foreign affairs, ranging from Afghanistan to Vietnam. The policy on wages policy however covers somewhat less than 3 pages and the bulk of that has been added in the last 3 years. It should however also be noted that the emphasis on foreign affairs has at least a positive element, in that it is a change from the generally more insular concerns of mainstream New Zealand society.

In looking at the response to structural change it is important to bear in mind that any institution, whether a trade union or any other, is a prisoner of its own history. In looking at how a union is responding to the situation today, one must bear in mind that both its personnel and its operating procedures are part of the history of both the trade union movement and our society over the 1950s and 1960s. That environment, and the public perception that grew with it, severely constrains the functions of trade unions. That perceived constraint upon the activities of unions is best summed up by looking at 2 strictures commonly applied to the trade union movement: "Keep out of politics" and "Act in the national interest." One does not have to be particularly perceptive to recognise that those 2 strictures are contradictary. For example if one is to keep out of politics but attempt to act in the national interest, it involves accepting someone else's definition of the national interest. Secondly, how do you define the national interest and yet exclude the aspirations of the largest group in the population? The fact that such nonsensical strictures could be applied to the organisations of workers in this country shows the extend to which the New Zealand populace has clearly misunderstood the functions of trade unions in a modern society. Despite their nonsensical nature, those highly contradictary statements clearly underline the common perception of trade unions which developed over the $1950 \mathrm{~s}$ and 1960s and is still prevalent today. It is a concept that was to be severely shattered by the events of the 1970s, and the trade union response to them. Before turning to those events and those responses however, let us look at longer term social changes occurring that will continue to influence union development.

\section{Longer term social changes influencing trade unions}

The growing proportion of women workers over the last 2 decades has had important implications for trade unions. Those implications can be seen as falling within 3 categories. First, it means that unions today have a membership with different aspirations and needs. The ability of unions to respond to those differing aspirations and needs will be a key element in their future success. To a certain degree unions have attempted to respond, but one only needs to look back at the very patchy response of unions to the opportunities afforded by the Equal Pay Act and the Human Rights Commission Act in the mid-1970s to realise that union consciousness about those issues had a long way to go. Only last year we had the particular case of the Fire Brigades Union still wishing to exclude women from that occupation.

The second major implication, for the trade union movement, of the increased number of women workers is the effect upon wage bargaining itself. The development of equal pay was a major change in many bargaining structures. Large numbers of awards had to be modified to remove the discriminatory rates that had applied in them for many years. It is quite clear that many unions did not find this process an extremely comfortable one. Today, discriminatory female rates have largely disappeared from industrial awards and agreements but this does not mean that all unions are seriously pursuing the rights of women to follow careers into the higher paid occupations of most industries. The desire of women to enjoy equal opportunities as well as equal pay still needs to be honestly faced by the trade union movement.

Another effect upon wage bargaining is slightly less direct, but still vitally important. With large numbers of women now employed in the workforce, the concept of the family 
wage is nearly dead. Looking at the household surveys produced by the Department of Statistics it is clear that something less than 20 percent of households now fall into the category of a single income family with children. In most New Zealand households, the earnings of both adults are important determinants of household income. This implies that the orientation of formal wage fixing around the idea of a man supporting his wife and children is totally obsolete. This has important implications for union concepts such as the minimum living wage and approaches to issues such as taxation. However, its most important implication is that the traditional philosophical base of bargaining will need to adjust dramatically to the changed circumstances.

A further important phenomenon has been the increasing involvement of women in trade union affairs. In this regard Sonja Davies' election as Vice President of the FOL should be seen not as the completion of a process but one small step on the way towards greater involvement by women in trade unions. It is important to note that something less than 20 percent of the delegates to the May 1983 annual conference were women. It is probable that the involvement of women in trade union affairs will increase as the economic and social pressures on women intensify. The rationale for that increased involvement of women in trade unions has been evidenced by recent events.

Those women who remain in the workforce have had to put up with the removal of so-called privileges like time off for school holidays and cuts in working hours often accompanied by increases in job content. The recent crisis has also highlighted an issue which the trade union movement as a whole has yet to face up to, sexual harrassment. The economic crisis and Government spending cuts have also taken their toll of women at home. Trying to balance the family books has become impossible, and violence in the home has increased dramatically with the increase in unemployment. Following lay-offs in the Hutt Valley at the end of 1982, the Lower Hutt Women's Refuge reported a dramatic increase in the number of women contacting them for help.

To add insult to injury, the idea that for some reason men have more right to jobs than women has flourished in this crisis and the Government and employers have played their part in fostering the idea that women workers are responsible for unemployment, inflation, the breakup of the nuclear family, juvenile delinquincy and associated evils. It is a matter of concern that women workers in addition to meeting these attitudes in employers and politicians, encounter them equally in male trade unionists. Nonetheless the union movement has begun to respond more positively to the needs of women.

One of the important developments in this area has been the growth of womens subcommittees at trades council level. This development can only lead to a much greater involvement of women in the trade union movement, acceptance of its goals and understanding that the workforce is not composed of men alone. One by-product is that unions will learn to understand that the fight for women's rights is of equal importance with the fight for workers rights. Unions are increasingly realising that if they ignore the special problems faced by half the population then they can only fail in their overall task of improving the lot of all workers.

As New Zealand's industrial base has grown, the workforce in many occupations has become increasingly distinguished not so much by skill, or age, or background but by the colour of its skin. As the economy shrinks, the effects are felt most severely by those sections of the population who work in jobs which are disappearing. Maori and Pacific Island workers are over-represented in the figures for redundancy and unemployment. The same society which has determined over the last century that Maori workers and - more recently - Pacific Island workers, shall not have access to any but the lowest paid duties and most difficult jobs has, as a result, also determined that they are the first to go onto the industrial scrap heap.

The trade union movement is finally realising that it is part of the society which has treated Maori and Pacific Island workers with such oppression. It is recognising that it is now essential that, as a movement, it seeks to make good that past. As the economic situation worsens, it is obvious that ethnic differences will continue to divide the workers of the country. The unions are realising that it is only by genuinely listening to the view- 
points of other ethnic groups that the white majority in the trade union movement can develop progressive policies and actions to deal with the problems which will arise.

The FOL has formed the Maori and Pacific Island advisory committee to advise the executive on specific areas of concern affecting Maori and Pacific Island workers. Its function is to give advice to the national executive on those matters which affect Maori and Pacific Island workers and their families. The work of the committee is only at its initial stages, but it raises the point that the trade union movement is starting to recognise the wide areas of concern with which it must be involved if it is going to address the needs and aspirations of workers in New Zealand society today.

The last 2 decades have also seen a growth in the white collar unions. The growing organisation of unions such as the Clerical Workers Union has brought trade unions face to face with a different set of issues than confronted traditional unions. Those issues include the organisation of workers in very small work places, the organisation of workers who are close to management in both their job location and in their outlook and the health and safety aspects of non-industrial work.

I raise these points about general social change because it is important that, in looking at the unions response to structural change, we must bear in mind that some change would have occurred anyway. The union movement has increasingly faced the reality that New Zealand trade unions are not solely composed of white men in boiler suits.

\section{The impact of change and the trade union response}

I do not wish to bore with a further recital of the economic changes which have hit New Zealand over the last decade, but it is important to consider the consequences faced by trade unions. Real incomes were no longer able to rise without conflict, either between unions and other groups in the community, or between unions themselves. A high level of Government intervention in wage bargaining itself became the norm over the 1970s and redundancy negotiations became a major element of trade union work. Restructuring and the fear of losing jobs drove unions into considering issues such as industrial development which had not been their function for some considerable time. A very high level of unemployment undercut the bargaining strength of many New Zealand trade unions and there was a perceived erosion of the benefits of the welfare state.

It is not surprising, given the past, that the trade union response would be defensive and concentrate on defending hard won rights and conditions. Thus, over the last decade, there has been an increasing number of campaigns aimed at defending the rights to negotiate, to preserve real wage levels and so on. This obscures the fact that there has also been a cohesive long term approach adopted which is not only accepting change but also pursuing it. That long term response has taken the form of an emphasis on organisation and education; concern about occupational health and safety; a major debate in union circles about wage bargaining strategy and the development of an alternative economic strategy. It is to these aspects of the response to structural change that I now wish to turn.

An emphasis on organisation and education is an important element in the process of facing up to change. In the final analysis, trade union effectiveness is determined by how well trade unions are organised, and how well they reach their members. You can talk about policy issues until you are blue in the face but, from a union point of view, the most important of all is the development of effective grass roots organisation. This is an essential precondition of change. Nothing else can succeed unless the unions can reach their membership and make union policy realistic to those members. The result of the 1981 election and the activities surrounding the Springbok tour showed quite clearly that union policy was out of touch with a wide range of union members.

Unions are realising increasingly that other policies cannot succeed until an effective mechanism is developed to make their policies acceptable, and ideas about changing them come up from the shop, office and factory floors. More effective grass roots involvement entails a number of consequences, all of them being closely interrelated. There is a need for 
democratic structures which are flexible enough to enable a diversity of opinions to be expressed and a collective approach worked out. Job delegates need to be effective and union officials responsive; resources must be adequate, and the membership keen and interested in developing the union; and as a corollary there must be a policy of trade union education and effective training for delegates, officials and members alike.

At the last annual conference of the FOL, a policy paper on trade union education was adopted. This issue was seen clearly as being directly related to the question of union organisation and the achievement of union policy objectives. It was clearly seen that more resources had to be put into educating rank and file members, officials and delegates, otherwise union policies would mean very little. That policy paper looked at issues such as the general objective of trade union education, the specific objectives of national federations such as the CSU and the FOL, for education, and the provision and control of educational facilities within the trade union movement.

In the current economic and political climate trade union priorities reorient themselves around survival for the trade union movement itself. There has been a tendency to neglect areas of work which are essential to the spirit of trade unionism and one such area is occupational health and safety. This year will see the launching of an occupational health and safety project, for which funding has been obtained from the Occupational Safety Trust Board, to be overseen by a committee made up of FOL and CSU representatives. It is intended that this project would aim to develop a comprehensive review report on trade union involvement in occupational health and safety in New Zealand, and to increase discussion and awareness of health and safety matters in the trade union movement throughout the country. From this project, it is hoped that specific proposals can be developed by the trade union movement for occupational health and safety and that these proposals will be endorsed and implemented by the trade union movement. The development of the occupational health and safety project can be seen as a direct response to the rapidly changing technology with which workers are faced today. It is an area that has been taken for granted for far too long, and unions are now realising that they have allowed their concern about this important issue to take too secondary a role. The development of a health and safety project is seen as one step towards a reorienting of priorities.

The 1983 annual conference of the FOL also saw a long debate upon wage bargaining. The conference had to discuss a report developed by a trade union working party on wage fixing and the use of a working party in this way is, in itself, an important change in the functioning of trade union organisation. In facing up to the issues surrounding wage bargaining, unions were confronted with 2 major issues. Firstly the probable economic situation for the rest of the 1980s indicates a different bargaining environment from that of the 1950s and 1960s. Secondly, the objective of achieving a minimum living wage is not consistent with the maintenance of an old bargaining system combined with the preservation of rigid relativities. If the minimum living wage concept is to have meaning at all, then unions have to find a way in which the relativity system can be modified, or find different methods of delivering the minimum living wage, or make drastic modifications to the bargaining system itself. Those 2 issues are fundamental to the discussions upon wage bargaining policy.

There are several important issues which have to be considered when one looks at the future of any wage bargaining system: The first of these is the extent to which a centralised result or a decentralised result is desirable. A tendency in the last few years has been for a very centralised pattern to emerge. Given the union movement's concern for the lower paid, it is likely that such a strategy will be pursued. This will bring union bargaining objectives into conflict with the expressed desire of employers and the Government for a more decentralised approach and will affect the amount of influence and control exerted by the Government. The New Zealand system has tended to have a high degree of Government influence in the past. Given the likely economic situation over the next decade, it is improbable that any responsible Government would not wish to exert influence on wage bargaining in the foreseeable future. The issue for unions may very well be how to influence wider Government policies as a trade-off against the reality of Government influence 
on wage bargaining. In this regard, unions realise that incomes are directly affected by tax and expenditure policies and any wage increase can be easily offset by changes in those policies. This raises the question of whether bargaining is about economy wide issues such as employment, inflation and growth, or union specific issues such as relativities and margin for skill. In the past, bargaining has concentrated on industry-specific issues, although, in reality, actual wage movements have tended to reflect movements in the cost of living. The probable state of the economy over the rest of the 1980s does suggest that economy wide issues will exert more influence than in the past. The involvement of workers in the fixing of wages is a key requirement of any system. Recent Government policy has been to attempt to undermine this involvement by unilaterally granting or withholding wage increases. Regardless of the shape of any future wage bargaining systems, unions will want to place a great deal of emphasis on maximising workers involvement in wage fixing.

The report of the working party attempted to recognise the serious difficulties faced by unions and that the system existing prior to the wage freeze had both important advantages and serious disadvantages. While there were people arguing that "it was better the devil you know than the devil you don't" quite a number of unionists clearly understood that, with the imposition of the wage freeze on 22 June last year, the Prime Minister had disembowelled the devil that unions knew and we had not the strength to resurrect that particular devil. Thus, there has been a serious attempt within unions to face up to the type of structure necessary to meet the requirements of wage bargaining over the next decade. That debate has tended not just to focus on arguments about returning to the old system but much more on what changes are necessary to make a viable system in the $1980 \mathrm{~s}$.

In this regard it is important to note, that after one weighs up the advantages and disadvantages of the system that existed prior to this freeze, one major question is the viability of that system. It has become clear over the last 12 months that the legal protection granted by awards is illusory. Unions have seen the tearing up of redundancy agreements, and the easy modification of working hours. The fact that it is so easy for awards to be breached by employers makes it clear to unions that the only real protection of wages and conditions is the extent to which workers are prepared to defend them. It also becomes clear that unions cannot rely upon the supposed legal protection of the old system to compensate for the lack of union organisation. A further point about the viability of the system concerns credibility. The 1970s have been such a sustained burst of Government intervention in the system that to argue that the New Zealand wage fixing system represents a form of free collective bargaining is a dangerous myth. Recognition of this myth has been one of the important changes in trade union policy over the last 12 months. This has lead to a quite intensive debate about the role of Government and its influence upon wage levels.

In attempting to develop a trade union approach to the wage fixing system, 2 interunion problems have to be borne in mind. First, no single wage fixing system was likely to be absolutely acceptable to all unions and unions with different structures and backgrounds would be suited by different bargaining systems. And secondly the immediate pressure for change in the wage fixing system did not come from unions but rather from sources which sought to further hinder union activity in influencing wage levels. Because of those factors there was a strong presumption in union terms for the retention of a wage fixing system enshrined in the Industrial Relations Act together with the right to take general wage order cases to the Arbitration Court. The issue therefore became one of arguing for previously held bargaining rights.

It was recognised however, that the FOL and its affiliated unions could not ignore the pressure for change in Government and employer circles. Neither could it fail to recognise the pressure for change amongst unions themselves. That pressure identified a number of areas of potential change. In the first instance there is pressure for some more formalised system of wage control as regards the basic annual wage movement as opposed to the experience of the last decade or so of ad hoc Government interference. A realistic view would be that the union movement recognise the economic constraints on the level of wage movement. The most acceptable method would be by tripartite consultation, with all 
parties having access to sufficient economic data and forecasts. Such a consultation could set a wage path which could be exceeded where productivity or some other factor demonstrably justified a movement outside the agreed pattern.

There is an immediate problem in that the present Government's policies are such that no areas of income agreement can be reached with that Government. There needs to be an element of trust and understanding on all sides for such an operation to succeed and such understanding must cover the whole range of social and economic policies. Therefore there is the short-term concern that the Government's policies themselves stand in the way of a wage fixing system reformed in this direction. Any successful tripartite system cannot operate on the present definition of one man, one vote - that definition being that one man has the one vote.

The second area of employer and Government concern is the elimination of several tiers of bargaining in some industries or sections of industry. That matter is one which could be most productively discussed by the parties to the relevant awards and agreements. It is not realistic to eliminate such dual or multiple levels of bargaining in all instances where systems have evolved to meet industry needs. In any event, it is not an area which requires legal change but in fact requires the coordination and co-relation of different levels of bargaining in our wage fixing system.

An important feature of the success of any new wage bargaining system will be the extent to which the inter-relationship between national awards on one hand and house agreements on the other can be clarified and improved.

The third area of Government and employer concern is for an ending of the relatively fixed relativity structure in the system. The relativity structure is a matter of practice, not law, and has been utilised in bargaining for many years by both employers and unions. The Industrial Relations Act itself does not predetermine rigid relativities and the answers to problems in this area are really in the hands of the bargaining parties themselves. It is clear, if one does wish to break up the relativity structure as it exists now, that there is a need to do something to protect the low paid. The working party accepted that the means by which this could be done in the short term were Government action through such measures as an increase in the minimum wage and the use of properly targeted tax and expenditure policies. If the fiscal system can be operated effectively to provide a reasonable floor for household incomes then unions are more likely to accept the need to adjust the relativity structure over and above that basic floor.

It would be a braver person than myself who would be prepared to forecast what shape the wage bargaining structure will take after 29 February next year. Like many others, when I heard that the freeze had been extended to 29 February, my first reaction was to check that 1984 was a leap year. Failure in the past has been due to many factors; not the least of them is the lack of a clear definition from the Government as to what changes it wishes to see while at the same time loudly proclaiming the desirability of change.

It is thus important to set an agenda and in fact any agenda is likely to be dominated by 3 items: concern about the relative position of the lower paid; recognition of the economic constraints on bargaining; and greater flexibility than in the past.

When one establishes the vital issues in that way, the framework of a possible solution begins to emerge. It is possible that the position of the lower paid can be largely dealt with by tax and expenditure policies targeted more effectively than they are currently; that tripartite consultations on the parameters of wage movements could be held. To be successful that would involve: a willingness to negotiate by all parties; the provision of full information; and ratification of any agreement by union membership. Those elements were certainly not present in the last round in which trade unions were really confronted with virtually non-negotiable positions by the Government. National wage fixing cannot lead to greater flexibility. It is also highly unlikely that conditions can be negotiated at a national level. That may require some form of "exceptional circumstances" provision. Possibly, such a provision would not necessarily entail the return to former procedures but the establishment of new procedures. For example, bargaining across industry lines on the basis of multi-union multi-employer agreements. 
The development of an alternative economic strategy has become an important feature of union policy over the last 3 to 4 years. While it can be seen as fundamentally a response to the current restructuring programme there are a number of underlying reasons why unions have seen the development of an alternative economic strategy as important. The first reason comes from awareness that the understanding of unions as being only concerned about negotiating wages and conditions did not reflect the relativities of what determined living standards for workers. Unions have increasingly realised that workers' living standards are determined not only by wages and conditions but also by the taxes that they pay, the benefits they receive from Government expenditure, the inflation rates they face, their prospects of getting a job, and the overall direction (or lack of it) of economic development. Even if one limits the role of the unions to only being converned about the living standards of union members, it would still be necessary for the union movement to develop a position on such issues.

However the development of an alternative economic strategy stems from wider considerations than concern about living standards. As organisations of working people, unions must be concerned that the aspirations and aims of those people are reflected in economic policy. Part of that concern is about the full human development of workers and their ability to influence decisions that affect their lives. It is a rejection of the current system that operates on the mushroom technique. One of the important objectives of the alternative economic strategy is to alter that situation to one where workers have a greater say in the economic affairs of the nation. The economic strategy also brings me back to my point about keeping out of politics and acting in the national interest. The economic strategy is about working out a union definition of the national interest. It is about taking up the political option of determining what workers consider to be the national interest. This is an important point given that workers are proportionately the largest group whose "national interest" it is.

The alternative strategy is also about education. The level of economic debate in New Zealand is at a particularly low level. This becomes quite clear during election campaigns. The simplistic nonsense which get served up as economic policies in election years is accepted partly because people are confused about economics and believe it is something they can know nothing about. The alternative economic strategy is seen as a mechanism to assist in changing that situation and giving workers a chance to discuss economic issues amongst other workers, to develop their own ideas and to realise that workers have as good an understanding, if not a better understanding, of the economy than the politicians who posture so much about it.

Essential to the concept of the alternative economic strategy is the response of the trade union movement to an economic crisis of quite massive proportions. It is about a response to restructuring. At the present time, unions see restructuring as a dirty word because it has been carried out in a way that appears to be totally hostile to workers' interests. The alternative economic strategy is concerned about developing a restructuring programme that relates to workers' interests. It is accepting the reality that New Zealand's economy has serious structural problems and that major changes need to occur. The logical response to the current restructuring programme for unions cannot be to lie back and believe that one can just defend the status quo but rather respond to the crisis in a way that moves the economy more in line with the interests and aspirations of the people who unions represent.

The alternative strategy is also about a political response to that crisis. The lesson of history is that economic, social and political factors are always closely intertwined but never more closely than in a period of intense economic depression. The fact that Nazism and Fascism were possible in Europe in the 1920s and 1930s was directly attributable to the economic conditions of that time. Unless organisations like trade unions are able to develop a response that means something to the working class, then workers will be attracted towards a policy advocated by extremists of the right. Thus the alternative economic strategy is about developing a political defence against such a situation. The economic policy objectives in the economic strategy were originally determined by the 1981 annual conference of the FOL. While not wishing to go into detail, those objectives briefly sum- 
marised provided for: (1) A higher level of public ownership and control in the economy. (2) Full employment as a major priority of economic policy. (3) A boost to the incomes of the low paid. (4) An equitable tax system. (5) The encouragement of industries which will foster self reliance. (6) A more just international economic order. (7) The participation of workers in economic decision making.

The particular economic objectives set at the 1981 conference were medium term and, while their achievement would not realise the ultimate economic objectives of trade union organisations, they were intended to move the economy in that direction. The economic policy recommendations were based on 2 main premises. Firstly, that they are directed towards promoting the objectives outlined by the 1981 conference, and secondly that they are achievable within the medium term political and economic background. As a policy document the alternative strategy looks at 4 main policies in terms of balance of payment, national development, investment and the public sector.

I do not wish to dwell here on the detail of this strategy but it involves 4 important changes in traditional labour strategy which are significant for the future. First, is the change of emphasis in regard to the Government sector. As well as recognising the desire to have an active investment policy pursued by the State, the strategy also emphasises the need for the effective targeting of Government assistance. In other words, it moves away from the idea that all state spending must per se be a good thing but rather that such spending must be related to its objectives and whether those are being carried out in effective and fair ways. In other words, one must address the question of whether health spending should be on total energy centres or on community health centres.

The real issue in regard to the level of state involvement in the economy is not whether we have nationalisation, creeping socialism, or totally free markets. It is not whether $\mathrm{x}$ percent of GDP in the public sector equates with socialism or whether a smaller percentage equals a free market Nirvana. The issue is not what the state controls but who controls the state and why. The issues are to be seen in terms of accountability, direction and coping with New Zealand political economy. For instance, is the state really accountable to the people who elect governments? Are people fully informed so that democratic choices can be made? Are objectives clearly set and are they being pursued effectively? Is the money spent by the State achieving its objectives or not? Only in addressing those questions can one really answer the questions of whether enough resources are being allocated, too much, or too little. Unfortunately, in the New Zealand debate, it is sufficient to propose nonsense policies like across the board 3 percent cuts. I suppose that this has the advantage of enabling politicians and bureaucrats to ignore the real resource allocation questions. As to coping with New Zealand's political economy, questions seem to derive from a new version of the sermon on the mount "blessed are those who spend public funds for they shall inherit the marginal seats."

The second change in union economic policy is in the stance adopted to protection. In the past, import licensing has been seen almost as a policy in itself. The economic strategy looks at it as purely an instrument of policy and one that would be applied depending upon national development objectives. Thus, rather than accepting protection as the cornerstone of development policy, protection must be justified in the light of its contribution to development policy.

The third important area is the recognition that national development must recognise the constraints upon economic growth. The economic strategy looks at those constraints such as the balance of payments constraint and the savings constraint upon the New Zealand economy and the need to overcome those constraints to make growth sustainable in the long term. Perhaps the most important point about the strategy is that it is not seen as being set in concrete. It is seen as a flexible document to be amended as circumstances change. This is a different approach from union policy in the past which has tended to follow the approach that once policy has been adopted it becomes unchallengable. The strategy is seen as a continually growing document rather than as just a policy that is adopted and then left unchanged. 


\section{Implications}

The long term response that I have outlined above has important implications for trade union organisation and operation. Those implications have already been discussed in the previous section of this lecture. However the union response has important implications for other groups that operate within the bargaining environment, notably employers and Government. For employers it means that they will be increasingly confronted with a union movement that is concerned about much wider issues than just the normal bargaining concerns of wages and conditions. It will require a response from employers on a much broader front than has been the case. The implication for employers' organisations is whether or not they can be effective in developing employer opinion around those issues and whether they can do that in a democratic way. Certainly, recent evidence suggests that employers organisations are getting their act together in a much more co-ordinated way, but an important change that will be necessary will be a move away from the extreme academic concerns about free markets so willingly espoused by secretariats but so unwillingly practised by grass roots employers.

For the Government, the implications are probably more important because the development of both the approach to bargaining and the alternative strategy suggests an acceptance of Government influence in certain areas in exchange for a fuller consultation and an involvement in the development of wider economic policy. For unions that immediately poses the question of whether or not unions can effectively continue to negotiate with the 3 ring circus which has an accountant as ring master. The approach being developed by unions in regard to bargaining, to their own organisation and to the alternative economic strategy places enormous emphasis on major changes: in the way in which the economy is managed; wage negotiations carried out; economic information shared; and economic decisions made and followed.

From my own personal experience of being involved in the wage policy talks, I would suggest that such changes would be impossible within the present environment. Perhaps a few experiences are needed to show what I mean. In 1980 the employers and union organisations started working on a wage policy package which was mutually agreed between the parties only to be confronted with a Government which said it has reservations about it but was unable to detail those reservations. As a result, further work on the package collapsed and a possible major change in wage fixing procedures was derailed. In 1982, the union movement was confronted with the details of a wage-tax trade-off proposal one week before the FOL annual conference. This was after the Government had been saying for 18 months that it desired such a proposal. One has to ask if the Government really did have its act together in developing that proposal. One also has to ask whether it could reasonably have expected any success by such inefficiency. Only a few weeks ago at a meeting in the Beehive it was put to us that there were 3 options in terms of coming out of the freeze. When asked if those were the only options the Prime Minister's comment was that they were the options before us at the moment. This air of uncertainty and dithering makes decision making very difficult for all organisations particularly for unions which are so answerable in the final analysis to their membership.

In common with other institutions, the trade union movement likes some certainty and consistency in the way in which policy is developed and implemented. It has come through a period in which the wage fixing structure for example has changed virtually every second year over the last decade. One can only be amazed that the anger and frustration which has resulted from that has not spilled over in more dramatic ways than has been the case to date. It is common to condemn unions as reactionary dinosaurs living in the past. I think when one looks back on the situations unions have had to deal with over the last decade, one can only be surprised at the flexibility they have shown.

Like all institutions, the trade union response to the present structural change has shown up many weaknesses and many difficulties. I would suggest however that the weaknesses and inconsistencies in the union movement are not very different from weaknesses and inconsistencies shown in other institutions. It must be remembered that the 
public has a perception of unions related to the statements I made earlier that unions should not be political and should act in the national interest. The developing union response to structural change means that unions are going to be acting in the national interest or at least in the definition of the national interest that is realistic to their membership. That will bring unions in direct conflict with the idea that they should keep out of politics, as it is the national interest we are concerned about, not National's interest.

It will be argued that an independent union position challenges consensus. I am not one of those who believes that consensus is a good thing in itself. Generally one can achieve consensus in 3 situations, in times of national crisis like a war, (and in modern circumstances that could well be a very short lived consensus indeed), on matters that do not deeply affect people, and in the pursuit of mediocrity. Therefore the achievement of consensus will not solve our problems. Those problems can only be solved by a clear understanding of the divisions amongst us and effective resolution of those divisions. The changes currently occurring in the trade union movement will make union organisation much more responsive to change in the long run. To my mind the real issue is not whether unions will respond to change but whether New Zealand society is mature enough to cope with unions advocating change. 